\title{
Expression of transforming growth factor $\beta$ (TGF- $\beta$ ) may contribute, in part, to the variations in histogenesis and the prevalence of peritoneal dissemination in human gastric carcinoma
}

\author{
Masami Niki, Masao Toyoda, Eiji Nomura, Hisashi Shinohara, Motoyuki NaKamura, Kanji Nishiguchi, \\ and Nobuhiko TANigawa \\ Department of General and Gastroenterological Surgery, Osaka Medical College, 2-7 Daigaku-cho, Takatsuki-city, Osaka 569-8686, Japan
}

\begin{abstract}
Background. Alterations in the activity of transforming growth factor $\beta$ (TGF- $\beta$ ) in humans have been implicated in fibrosis, immunosuppression, development of cancer, and other disorders. Scirrhous gastric carcinoma is characterized by cancer cells that infiltrate rapidly in the stroma with extensive growth of fibroblasts and fibrous tissue. Hence, the majority of studies examining the role of TGF- $\beta$ in gastric carcinoma have focused on scirrhous carcinoma.

Methods. We undertook a retrospective immunohistochemical study of gastric carcinoma in order to characterize TGF- $\beta$ expression in malignant gastric lesions and to determine whether TGF- $\beta$ expression was related to disease progression. Results. TGF- $\beta$ expression in scirrhous gastric carcinomas was significantly higher than that in nonscirrhous gastric carcinomas. In patients with advanced gastric carcinoma with surgically curative resection, TGF- $\beta$ expression was significantly higher in those patients who developed peritoneal recurrence after surgery than in those who did not develop such recurrence. Patients with TGF- $\beta$ expression-positive tumors had significantly poorer survival than did those with TGF- $\beta$ expression-negative tumors $(P=0.017)$. In addition, multivariate Cox proportional hazard model analysis showed that TGF- $\beta$ immunohistochemical status was an independent prognostic factor $(P=\mathbf{0 . 0 0 3 1})$.

Conclusion. These data suggest that TGF- $\beta$ may contribute, in part, to the variations in histogenesis and to the prevalence of peritoneal dissemination in gastric carcinoma.
\end{abstract}

Key words Scirrhous gastric carcinoma - Transforming growth factor $\beta$. Peritoneal dissemination - Immunohistochemical study

Offprint requests to: $\mathrm{M}$. Niki

Received: August 4, 2000 / Accepted: November 15, 2000

\section{Introduction}

Transforming growth factor $\beta$ (TGF- $\beta$ ) consitutes a family of polypeptides which have important regulatory roles in a diverse series of processes, including angiogenesis, embryogenesis, inflammation, and immunosuppression [1]. There is evidence of altered expression of TGF- $\beta$ s in cancers [2], and certain tumors may both synthesize and respond to TGF- $\beta$ s [3]. It has thus been suggested that the growth of these tumors may be influenced by the autocrine secretion of TGF- $\beta$ [4]. TGF- $\beta$ is one of the most potent cytokines for promoting collagen synthesis by fibroblasts $[5,6]$. Yoshida et al. [7] demonstrated that TGF- $\beta 1$ mRNA was highly expressed in tumor cells of scirrhous gastric carcinoma. Mizoi et al. [8] reported, on the basis of immunoelectron microscopy, that the growth of cancer stroma was promoted by TGF- $\beta 1$ mainly secreted by stromal cells. But TGF- $\beta 1$ is generally secreted as a latent or precursor molecule, which may possibility be related to scirrhous gastric carcinoma. Mahara et al. [9] suggested that tumor cells in scirrhous carcinoma were capable of producing more active-form TGF- $\beta 1$ than nonscirrhous carcinoma, thus being responsible, in part, for the observed enhanced collagen deposition in the region.

Scirrhous gastric carcinoma (diffusely infiltrating carcinoma or Borrman's type IV carcinoma) is characterized by cancer cell infiltration and proliferation with extensive fibrosis in the stroma [10]. Although the prognosis of gastric carcinoma has recently improved, that of scirrhous gastric carcinoma has not [11]. One of the reasons for the poor prognosis of this type of carcinoma is the difficulty of detection in its early stage, in part because of the rapid proliferation of the cancer cells. When scirrhous gastric carcinoma cells invade the submucosa of stomach, the cancer cells proliferate rapidly, with fibrosis. The mechanisms responsible for the rapid proliferation are not clearly understood. The typical histological finding of scirrhous gastric 
carcinoma suggests that its development may be controlled by intercellular interactions between the cancer cells and neighboring stromal cells such as fibroblasts. Several studies have speculated on the potential participation of fibroblasts in the production of the extracellular matrix in gastric carcinomas [12,13].

We undertook a retrospective immunohistochemical study of gastric carcinoma in order to characterize TGF- $\beta$ expression in malignant gastric lesions and to determine whether the expression of TGF- $\beta$ was related to disease progression.

\section{Patients and methods}

\section{Patients}

The study analyzed 74 patients who had undergone resections for primary advanced gastric carcinomas (39 men and 35 women) at the Department of General and Gastroenterological Surgery, Osaka Medical College Hospital. Gastric carcinoma was classified morphologically as types I-IV (type I, nonulcerated polypoid lesion growthing into the lumen of the stomach; type II, an ulcerated, circumscribed disc-like tumor with clearly defined, sharp margin; type III, an ulcerated tumor that is not sharply circumscribed; type IV, diffuse, infiltrating type of gastric cancer that can involve the entire stomach) according to Borrmann's classification [14]. According to this classification, the patients were divided into two groups: those with scirrhous gastric carcinomas (35 patients who had Borrmann type IV gastric cancer) and those with nonscirrhous gastric carcinomas (39 patients with Borrmann types I through III cancers of the stomach). Forty-six patients underwent surgically curative resection, while 28 patients underwent noncurative resection. Twenty of the 46 patients had scirrhous carcinoma, while 26 patients had Borrman types I to III carcinoma (nonscirrhous carcinoma). Resected specimens, including the dissected lymph nodes, were examined histopathologically. Both the staging and histopathological diagnosis were classified according to the Japanese Research Society for Gastric Cancer [15].

Routine follow-up of these patients after surgery consisted of clinical evaluation every 2 months for the first 2 years, and every 3 months thereafter.

\section{Immunohistochemical staining}

Expression of TGF- $\beta$ was determined on formalin-fixed and paraffin-embedded tumor samples by an indirect immunohistochemical method. The antibody used was a chicken polyclonal antibody (RSD, lot number W247) at a 1:200 dilution for TGF- $\beta$. Briefly, tissue sections were deparaffinized in xylene, hydrated in phosphatebuffered saline, and blocked with normal rabbit serum. Slides were incubated overnight with primary antibody at the dilution described. Peroxidase-rabbit antichicken immunoglobulin (Zymed Laboratories, South San Francisco, CA, USA) was used as the secondary antibody. Sections were then developed with diaminobenzidine and hydrogen peroxide, which produced a brown precipitate. Sections were then counterstained with hematoxylin, dehydrated, and mounted. For positive controls, placental tissue was stained for TGF- $\beta$. For the negative control all reagents were used, except for the primary antibody. Samples with more than $10 \%$ positively stained tumor cells were defined as positive; otherwise, they were defined as negative.

\section{Statistical analysis}

All statistical analysis was performed with the SPSS 6.1 J software package for Macintosh (SPSS, Chicago, IL, USA). Clinical characteristics of the patients were analyzed in relation to the expression of TGF- $\beta$ and checked by the $\chi^{2}$ test. $P$ values of less than 0.05 were considered statistically significant. Overall survival curves were generated by the Kaplan-Meier method. The significance of survival differences between the patient groups was calculated according to the log-rank test.

\section{Results}

\section{TGF- $\beta$ expression in gastric carcinomas}

TGF- $\beta$ expression was identified mainly in the cytoplasm of cancer cells (Fig. 1). Overall, 41 of the 74 primary advanced gastric carcinomas expressed TGF- $\beta$ in their cancer cells $(55.4 \%)$. Table 1 shows the relationship between TGF- $\beta$ expression and clinicopathologic factors in the two groups of patients: the 35 scirrhous gastric carcinoma patients, and the 39 nonscirrhous gastric carcinoma patients. In regard to histological type, the poorly differentiated type was significantly higher in scirrhous carcinoma than in nonscirrhous carcinoma. TGF- $\beta$ expression in scirrhous gastric carcinoma $(74.3 \%)$ was significantly higher than that in nonscirrhous gastric carcinoma (38.5\%) (Fig. 2). In the 46 patients who underwent surgically curative resection, TGF- $\beta$ expression in scirrhous carcinoma patients was significantly higher in those patients who developed peritoneal recurrence after surgery than in those who did not develop such recurrence. Moreover, TGF- $\beta$ expression in nonscirrhous carcinoma patients was also significantly higher in patients who developed peritoneal recurrence after surgery than in those who did not (Fig. 3). 


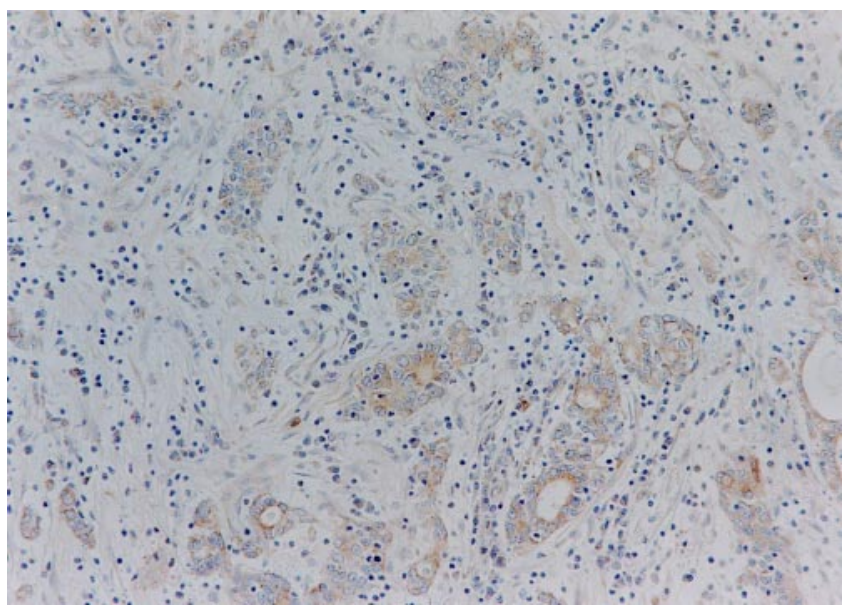

Fig. 1. Immunohistochemical staining for transforming growth factor (TGF)- $\beta$ in carcinoma tissues of the stomach. TGF- $\beta$ expression was identified mainly in the cytoplasm of cancer cells. $\times 200$

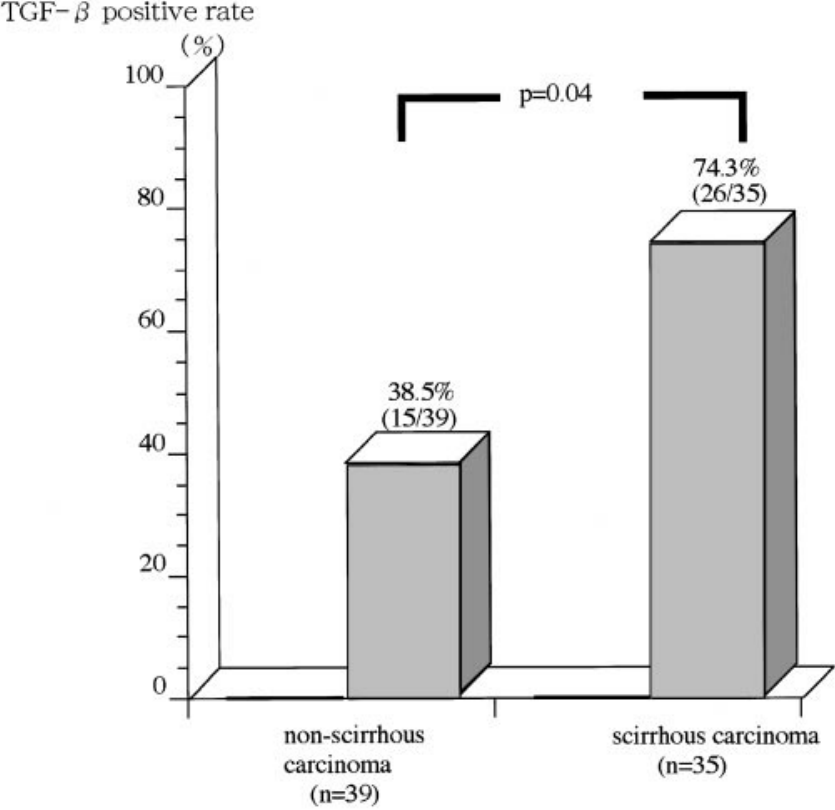

Fig. 2. TGF- $\beta$ expression in scirrhous gastric carcinoma patients was significantly higher than that in nonscirrhous gastric carcinoma patients

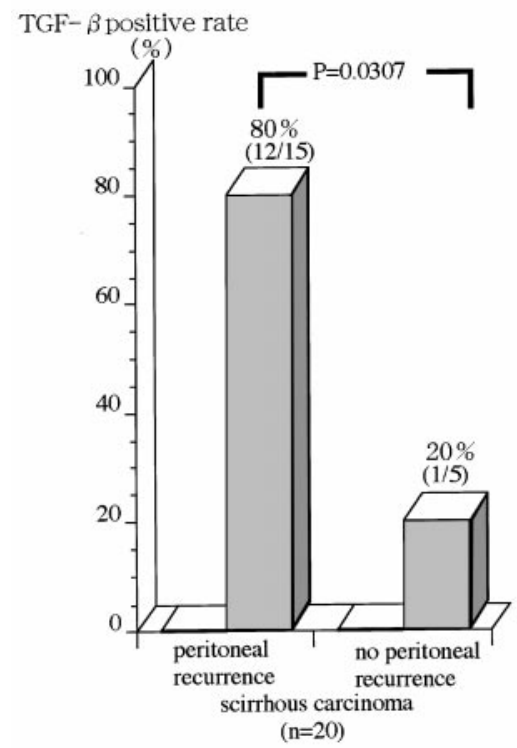

Analysis of prognostic factors in patients with advanced gastric carcinoma with surgically curative resection

Positive expression of TGF- $\beta$ in tumors was significantly correlated with poor prognosis compared with TGF- $\beta$-negativity $(P=0.047)$. We analyzed follow-up data in the 46 patients given curative resection, of whom 20 patients had scirrhous carcinoma, and 26 patients had nonscirrhous carcinoma. The patients were divided into two subgroups based on their TGF- $\beta$ expression; 25 patients whose tumors were positive for TGF- $\beta$ expression and 21 patients whose tumors were negative for TGF- $\beta$ expression. KaplanMeier plots demonstrated significantly worse prognosis in patients with tumors positive for TGF- $\beta$ expression $(P=0.017)$ (Fig. 4). In addition, multivariate Cox proportional hazard model analysis showed that TGF- $\beta$ immunohistological status was an independent prognostic factor $(P=0.0031)$ (Table 2$)$. 
Table 1. Relationship between TGF- $\beta$ expression and clinicopathologic factors in two groups: 35 scirrhous gastric sarcinomas and 39 nonscirrhous gastric carcinomas

\begin{tabular}{|c|c|c|c|c|c|c|}
\hline & \multicolumn{4}{|c|}{ Scirrhous carcinoma $^{\mathrm{a}}(n=35)$ non-scirrhous carcinoma ${ }^{\mathrm{b}}(n=39)$} & \multicolumn{2}{|c|}{$P$} \\
\hline & $\mathrm{TGF}-\beta(+)^{\mathrm{c}}$ & TGF- $\beta(-)^{\mathrm{d}}$ & $\mathrm{TGF}-\beta(+)^{\mathrm{c}}$ & TGF- $\beta(-)^{\mathrm{d}}$ & a vs b & c vs d \\
\hline Age (years) & $45.8 \pm 9.5$ & $50.3 \pm 15.2$ & $60.7 \pm 10.1$ & $61.1 \pm 15.4$ & NS & NS \\
\hline \multicolumn{7}{|l|}{ Sex } \\
\hline Male & $12(46.2)$ & $5(55.6)$ & $10(66.7)$ & $12(50.0)$ & \multirow[t]{2}{*}{ NS } & \multirow[t]{2}{*}{ NS } \\
\hline Female & $14(53.8)$ & $4(44.4)$ & $5(33.3)$ & $12(50.0)$ & & \\
\hline \multicolumn{7}{|l|}{ Depth of tumor invasion } \\
\hline $\mathrm{t} 2$ & $6(23.1)$ & $1(11.1)$ & $8(53.3)$ & $10(41.7)$ & \multirow[t]{3}{*}{ NS } & \multirow[t]{3}{*}{ NS } \\
\hline $\mathrm{t} 3$ & $16(61.5)$ & $6(66.7)$ & $7(46.7)$ & $11(45.8)$ & & \\
\hline $\mathrm{t} 4$ & $4(15.4)$ & $2(22.2)$ & 0 & $3(12.5)$ & & \\
\hline \multicolumn{7}{|l|}{ Lymph node metastasis } \\
\hline n0 & $6(23.1)$ & $1(11.1)$ & $3(20.0)$ & $4(16.7)$ & \multirow[t]{5}{*}{ NS } & \multirow[t]{5}{*}{ NS } \\
\hline $\mathrm{n} 1$ & $7(26.9)$ & $3(33.3)$ & $4(26.7)$ & $10(41.7)$ & & \\
\hline $\mathrm{n} 2$ & $7(26.9)$ & $1(11.1)$ & $6(40.0)$ & $5(20.7)$ & & \\
\hline n3 & $4(15.4)$ & $4(44.4)$ & $2(13.3)$ & $4(16.7)$ & & \\
\hline n4 & $2(7.7)$ & 0 & 0 & $1(4.2)$ & & \\
\hline \multicolumn{7}{|l|}{ Histological type } \\
\hline pap & 0 & 0 & $1(6.7)$ & $6(25.0)$ & \multirow{6}{*}{$P<0.01$} & \multirow[t]{6}{*}{$P<0.01$} \\
\hline tub1 & 0 & 0 & $2(13.3)$ & $1(4.2)$ & & \\
\hline tub2 & $1(3.8)$ & 0 & $4(26.7)$ & $2(8.3)$ & & \\
\hline por & $21(80.8)$ & $5(55.6)$ & $8(53.3)$ & $9(37.5)$ & & \\
\hline sig & $4(15.4)$ & $3(33.3)$ & 0 & $4(16.7)$ & & \\
\hline muc & 0 & $1(11.1)$ & 0 & $2(8.3)$ & & \\
\hline \multicolumn{7}{|l|}{ Vessel invasion } \\
\hline Presence & $15(57.7)$ & $6(66.7)$ & $13(86.7)$ & $12(50.0)$ & \multirow[t]{2}{*}{ NS } & \multirow[t]{2}{*}{ NS } \\
\hline Absence & $11(42.3)$ & $3(33.3)$ & $2(13.3)$ & $12(50.0)$ & & \\
\hline \multicolumn{7}{|l|}{ Lymphatic invasion } \\
\hline Presence & $11(42.3)$ & $3(33.3)$ & $2(13.3)$ & $12(50.0)$ & \multirow[t]{2}{*}{ NS } & \multirow[t]{2}{*}{ NS } \\
\hline Absence & $15(57.7)$ & $6(66.7)$ & $13(86.7)$ & $12(50.0)$ & & \\
\hline \multicolumn{7}{|l|}{ Surgical curability } \\
\hline Curative resection & $15(57.7)$ & $5(55.6)$ & $10(66.7)$ & $16(66.7)$ & \multirow[t]{2}{*}{ NS } & \multirow[t]{2}{*}{ NS } \\
\hline Noncurative resection & $11(42.3)$ & $4(44.4)$ & $5(33.3)$ & $8(33.3)$ & & \\
\hline \multicolumn{7}{|l|}{ Stage } \\
\hline $\mathrm{Ib}$ & $3(11.5)$ & 0 & $2(13.3)$ & $2(8.3)$ & \multirow[t]{4}{*}{ NS } & \multirow[t]{4}{*}{ NS } \\
\hline II & $1(3.8)$ & 1 (11.1) & $1(6.7)$ & $3(12.5)$ & & \\
\hline IIIa, IIIb & $14(53.8)$ & $3(33.3)$ & 7 (46.7) & $15(62.5)$ & & \\
\hline IVa, IVb & $8(30.8)$ & $5(55.6)$ & $5(33.3)$ & $4(16.7)$ & & \\
\hline
\end{tabular}

TGF, transforming growth factor; pap, papillary adenocarcinoma; tub1, well differentiated tubular adenocarcinoma; tub2, moderately differentiated tubular adenocarcinoma; por, poorly differentiated adenocarcinoma; sig, signet-ring cell carcinoma; muc, mucinous adenocarcinoma; 2 , tumor invasion of muscularis propria or subserosa; $\mathrm{t} 3$, tumor penetration of serosa; $\mathrm{t} 4$, tumor invasion of adjacent structures; $\mathrm{n} 0$, no regional lymph node metastasis; $\mathrm{n} 1, \mathrm{n} 2, \mathrm{n} 3$, and $\mathrm{n} 4$, metastasis in group 1, 2, 3, and 4 lymph nodes, respectively; NS, not significant

\section{Discussion}

TGF- $\beta$ is a cytokine, and has multiple activities in cell growth, tissue differentiation, accumulation of extracellular matrix, and immune function $[1,16,17]$. TGF- $\beta$ has also been reported to affect tissue morphogenesis, including tubular formation. Santos and Nigam [18] observed that TGF- $\beta$ had the potential to inhibit tubular formation in a cell line derived from canine kidney that is inducible by hepatocyte growth factor.

Although these effects of TGF- $\beta$ on cell growth, tissue differentiation, and morphogenesis have been well documented in vitro, the role of TGF- $\beta$ in human cancer development is not fully understood. In the present study, we investigated the expression of TGF- $\beta$ in human gastric carcinomas. Kai et al. [19] reported that strong staining for the expression of TGF- $\beta 1$ and TGF- $\beta 2$ was detected in about one-third of diffusetype carcinoma cells, but not in intestinal-type cells. Carcinoma cells scattered as single cells showed very strong staining for TGF- $\beta$ s and their receptors. Some of these cells may have been simply poorly differentiated, but others could have been dissociated by the function of TGF- $\beta$. In an attempt to clarify the mechanism of the prevalence of peritoneal dissemination in scirrhous gastric carcinoma in the present study, we examined not only the protein expression of TGF- $\beta$ but also TGF- $\beta 1$ mRNA expression in gastric carcinomas. 


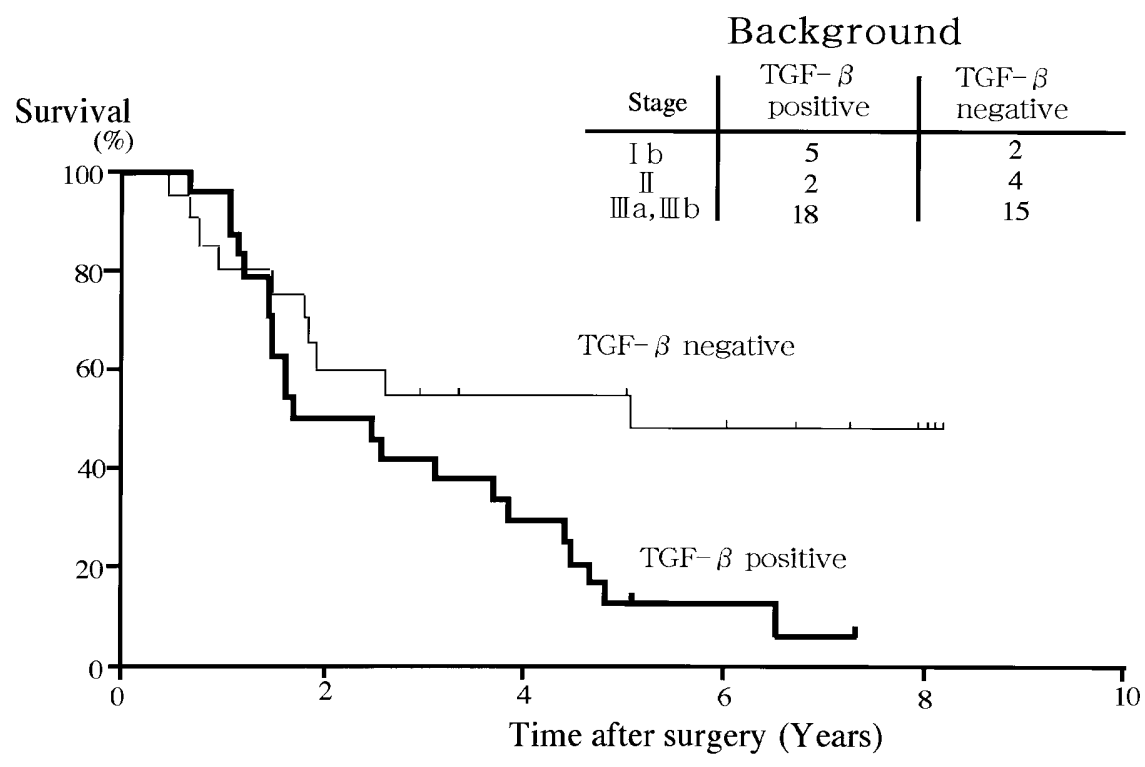

Fig. 4. Correlation between TGF- $\beta$ expression and overall survival. The 46 patients with curative resection were divided into two subgroups based on their TGF- $\beta$ expression; 25 patients whose tumors were positive for TGF- $\beta$ expression (thick line) and 21 patients whose tumors were negative for TGF- $\beta$ expression (thin line). Kaplan-Meier plots demonstrated significantly worse prognosis in patients with tumors positive for TGF- $\beta$ expression $(P=0.017$ by log-rank test)

Table 2. Multivariate analysis showing independent predictors of overall survival according to the Cox proportional hazards model

\begin{tabular}{|c|c|c|c|}
\hline Clinicopathologic factors & $\chi^{2}$ & $P$ & Relative risk (95\% confidence interval) \\
\hline Age (years; $\leqq 60$ vs $>60)$ & 0.6845 & 0.5659 & $1.3658(0.4711-3.9593)$ \\
\hline Sex (male vs female) & 0.2765 & 0.5989 & $0.8111(0.3716-1.7702)$ \\
\hline Histological type (well vs poorly differentiated) & 0.2761 & 0.5992 & $1.3303(0.4588-3.8569)$ \\
\hline Serosal invasion (presence vs absence) & 0.3531 & 0.5523 & $1.3309(0.5184-3.4169)$ \\
\hline Macroscopic type (types $1,2,3$ vs type 4 ) & 2.2351 & 0.1349 & $1.8635(0.8240-4.2143)$ \\
\hline Lymph node metastasis (presence vs absence) & 0.3409 & 0.3409 & $1.4738(0.6634-3.2738)$ \\
\hline Lymphatic invasion (presence vs absence) & 0.5298 & 0.5298 & $1.4640(0.4458-4.8075)$ \\
\hline Vessel invasion (presence vs absence) & 0.0744 & 0.7851 & $1.1219(0.4908-2.5645)$ \\
\hline TGF- $\beta$ (positive vs negative) & 8.7588 & 0.0031 & $3.6420(1.5473-8.5722)$ \\
\hline
\end{tabular}

On immunohistochemical analysis, scirrhous carcinoma stained for TGF- $\beta$ more intensely than did nonscirrhous carcinoma. Furthermore, scirrhous carcinoma had a more intense signal for TGF- $\beta 1$ mRNA than nonscirrhous gastric carcinoma. These findings are compatible with the report of Yoshida et al. [7], who found increased expression of TGF- $\beta 1$ mRNA in scirrhous gastric cancer tissues. Hirayama et al. [20] found intense staining of TGF- $\beta 1$ on penetrating cells of the linitis plastica type of gastric cancer: this finding is consistent with the notion that cancer cells likely produce TGF- $\beta 1$ to promote the proliferation of nearby stromal tissue. On the other hand, Mizoi et al. [8] have claimed that, despite the finding that both tumor cells and stromal cells were stained positively, fibrosis in gastrointestinal cancer is promoted by TGF- $\beta 1$, mainly secreted by stromal cells.

An even more important observation was that scirrhous cell lines secreted mainly active TGF- $\beta 1$, while nonscirrhous cells secreted latent TGF- $\beta 1$. In fact, Mahara et al. [9], who studied established cell lines, clearly demonstrated that TGF- $\beta 1$ was indeed secreted in the culture medium in an appreciable amount. TGF$\beta$ s exert their effects through binding to specific cell surface receptors. Several different molecules have been shown to bind TGF- $\beta$ s. Among them, T $\beta$ R-I and $\mathrm{T} \beta \mathrm{R}-\mathrm{II}$ play a major role in signal transduction of TGF$\beta$ s. Receptors for TGF- $\beta$ have been studied in gastric carcinoma cell lines [21,22]. One of the interesting findings was the differential expression of these receptors in two types of gastric carcinomas; a significantly higher frequency of receptor staining was observed in diffuse-type carcinoma than in intestinal-type in these two studies. Thus, in the diffuse type of gastric carcinoma, both $\mathrm{TGF}-\beta \mathrm{s}$ and their receptors were expressed more frequently than in the intestinal type.

Generally, the intestinal type of gastric carcinoma is considered to be more differentiated than the diffuse type. Considering the high frequency of TGF- $\beta$ expression in highly invasive tumors as well, TGF- $\beta 1$ and TGF- $\beta 2$ may play important roles in the progression of gastric cancer. However, it has been shown that certain 
malignant tumors become resistant to the growth inhibitory effect of TGF- $\beta$ [16]. Some TGF- $\beta$-resistant cells have intact TGF- $\beta$ receptors, and, thus, the intracellular signaling pathways are presumed to be perturbed in these cells [23]. Kai et al. [19] reported that large amounts of TGF- $\beta$ secreted by these TGF- $\beta$-insensitive carcinoma cells may suppress immune function or modulate the adhesion molecules on endothelial cells to contribute to the higher incidence of lymphatic invasion.

In the present study, TGF- $\beta$ expression was significantly higher in scirrhous gastric carcinoma than in nonscirrhous gastric carcinoma. In the patients with advanced gastric carcinoma who underwent curative resection, TGF- $\beta$ expression was significantly higher in those who developed peritoneal recurrence than in those who did not. Carcinoma with high TGF- $\beta$ expression was associated with a higher incidence of peritoneal recurrence than low TGF- $\beta$ expression. Our findings indicate that high TGF- $\beta$ expression is a useful prognostic factor in human advanced gastric carcinoma. Our results support the idea that the expression of TGF- $\beta$ correlates with both mechanism of the formation of scirrhous gastric carcinoma and with the development of peritoneal recurrence. These data suggest that TGF- $\beta$ may contribute, in part, to the variations in histogenesis and to the prevalence of peritoneal dissemination in gastric carcinoma.

\section{References}

1. Roberts AB, Sporn MB. The transforming growth factor-betas. In: Sporn MB, Robert AB, editors. Peptide growth factors and their receptors. Heidelberg, Berlin New York Tokyo: Springer; 1990. p. 419-72.

2. Barrett-Lee PJ, Travers MYT, Luqmani YA, Coombes RC. Transcripts for transforming growth factors in human breast cancer: clinical correlates. Br J Cancer 1990;61:612-17.

3. Hsuan JJ. Transforming growth factors beta. Br Med Bull 1989;45:425-37.

4. Roberts AB, Thompson NL, Heine U, Flanders C, Sporn, MB. Transforming growth factor- $\beta$ : possible roles in carcinogenesis. Br J Cancer 1988;57:594-600.

5. Ignotz RA, Masssague J. Transforming growth factor- $\beta$ stimulates the expression of fibronectine and collagen and their incorporation into the extracellular matrix. J Biol Chem 1986;261: 4337-56.

6. Terui T, Niitsu Y, Mahara K, Fujisaki Y, Urushizaki Y, Mogi Y, et al. The production of transforming growth factor- $\beta$ in acute megakaryoblastic leukemia and its possible implications in myelofibrosis. Blood 1990;75:1540-8.
7. Yoshida K, Yokozaki H, Nimoto M, Ito H, Ito M, Tahara E. Expression of TGF- $\beta$ and procollagen type I and type III in human gastric carcinomas. Int J Cancer 1989;44:394-8.

8. Mizoi $T$, Ohtani $H$, Miyazawa $M$, Matsuno $S$, Nagura $H$. Immunoelectron microscopic localization of transforming growth factor- $\beta 1$ and latent transforming growth factor- $\beta 1$ and latent transforming growth factor- $\beta 1$ binding protein in human gastrointestinal carcinomas: qualitative difference between cancer cells and stroma cells. Cancer Res 1993;53:183-90.

9. Mahara K, Kato J, Terui T, Takimoto R, Hashimoto M, Murakami T, et al. Transforming growth factor- $\beta 1$ secreted from scirrhous gastric cancer cells is associated with excess collagen deposition in the tissue. Br J Cancer 1994;69:777-83.

10. Tahara E. Growth factors and oncogenes in human gastrointestinal carcinoma. J Cancer Res Clin Oncol 1990;116:12131.

11. Kiyasu Y, Kaneshima S, Koga S. Morphogenesis of peritoneal metastasis in human gastric cancer. Cancer Res 1981;41:12369 .

12. Naito Y, Kino I, Horiuti K, Fujimoto D. Promotion of collagen production by human fibroblast with gastric cancer cells in vitro. Virchows Arch B Cell Pathol 1984;46:145-54.

13. Yamamoto R, Ishii H, Tatsuta M, Nakamura H, Terada N, Komatu K, et al. Enhancement of mucus accumulation in a human gastric scirrhous carcinoma cell line (KATO-III) by fibroblast-tumor cell interaction. Virchows Arch B Cell Pathol 1990;59:26-31.

14. Borrmann R. Geschwülste des Magen und Duodenums. In: Hanke $F$, Lubarsch $\mathrm{O}$, editors. Handbuch der speziellen pathologischen Anatomie und Histologie vol.IV/I. Heidelberg New York Tokyo Berlin: Springer; 1926. p. 865.

15. Japanese Research Society for Gastric Cancer. The general rules for the gastric cancer study, 12th ed. Tokyo: Kanehara; 1993.

16. Lyons RM, Moses HL. Transforming growth factors and regulation of cell proliferation. Eur J Biochem 1990;187:467-73.

17. Massague J. Transforming growth factor- $\beta$ family. Annu Rev Cell Biol 1990;6:597-641.

18. Santos OFP, Nigam SK. HGF-induced tubulogenesis and branching of epithelial cells is modulated by extracellular matrix and TGF- $\beta$. Dev Biol 1993;160:293-302.

19. Kai T, Taketazu F, Kawakami M, Shimanuki K, Yamada S, Miyazono K, et al. Distribution of transforming growth factor- $\beta$ and its receptors in gastric carcinoma tissue. Jpn J Cancer Res 1996;87:296-304.

20. Hirayama D, Fujimori T, Satonaka K, Nakamura T, Kitazawa S, Horio M. Immunohistochemical study of epidermal growth factor and transforming growth factor- $\beta$ in the penetrating type of early gastric cancer. Hum Pathol 1992;23:681-5.

21. Ito M, Yasui W, Nakayama H, Yokozaki H, Ito H, Tahara E. Reduced levels of transforming growth factor- $\beta$ type I receptor in human gastric carcinomas. Jpn J Cancer Res 1992;83:86-92.

22. Park K, Kim S-J, Bang Y-J, Park J-G, Kim N-K, Roberts AB, et al. Genetic change in the transforming growth factor- $\beta$ (TGF- $\beta$ ) type II receptor gene in human gastric cancer cells: correlation with sensitivity to TGF- $\beta$. Proc Natl Acad Sci USA 1994;91:87726.

23. Franzen P, Ichijo H, Miyazono K. Different signals mediate transforming growth factor- $\beta 1$-induced growth inhibition and extracellular matrix production in prostatic carcinoma cells. Exp Cell Res 1993;207:1-7. 